\title{
$60^{\text {th }}$ Anniversary of the Famous Ethnographer-Tungusologist Tatyana Yur'evna Sem
}

\author{
Vladimir N. Davydov* \\ Museum of Anthropology and Ethnography RAS \\ (Kunstkamera) \\ 3 University emb., St. Petersburg, 199034, Russia
}

Received 09.10.2017, received in revised form 28.08.2018, accepted 04.09.2018

This publication is devoted to the $60^{\text {th }}$ anniversary of the famous scientist-tungusologist T.Yu. Sem. The article describes the contribution of T.Yu. Sem to ethnography and lists main works of the scientist.

Keywords: Tungus studies, Russian Ethnographic Museum, ethnography of the peoples of Siberia.

Research area: culturology.

Citation: Davydov, V.N. (2018). 60th anniversary of the famous ethnographer-tungusologist Tatyana Yur'evna Sem. J. Sib. Fed. Univ. Humanit. soc. sci., 11(9), 1386-1398. DOI: 10.17516/1997-1370-0311.

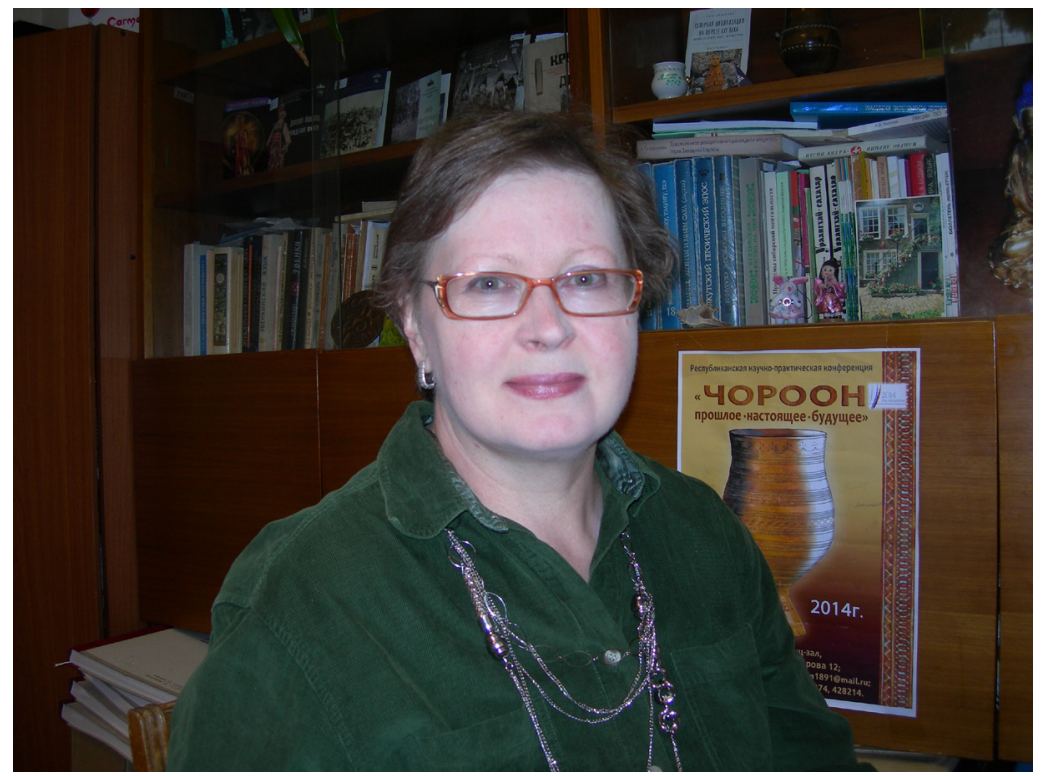

(c) Siberian Federal University. All rights reserved

* Corresponding author E-mail address: davydov.kunstkamera@gmail.com

This work is licensed under a Creative Commons Attribution-NonCommercial 4.0 International License (CC BY-NC 4.0). 
October 2017 marked the $60^{\text {th }}$ anniversary of Tatyana Yur'evna Sem, the wellknown ethnographer-historian, Candidate of Historical Sciences, leading research scientist of the Department of Ethnography of the Peoples of Siberia and the Far East in the Russian Ethnographic Museum (St. Petersburg). She was born on October 22, 1957 in Vladivostok in the family of famous in the Far East scholars. In 1980 she graduated from Leningrad State University with a degree in history, pedagogics, ethnography. In 1988 T.Yu. Sem finished the postgraduate course in the Institute of Ethnography (IE) RAS (Kunstkamera), specialising in the sector of Siberia. In 2001 she had an internship at the Museum of Anthropology and Ethnography (MAE) to write her candidate's thesis. In 2007 she defended her thesis at the Institute of the Peoples of the North (Herzen State Pedagogical University). The topic was: "The supreme pantheon of the Tungus-Manchu peoples (19-20 $0^{\text {th }}$ centuries): typology and semantics of images". Her scientific supervisor was A.M. Reshetov, the leading research scientist of the MAE RAS.

From September 1979 to the present (2017) T.Yu. Sem has been working at the Russian Ethnographic Museum in the Department of Ethnography of the Peoples of Siberia and the Far East. In 1991 she became a senior researcher. Since 1991 for 20 years already T.Yu. Sem has been a curator of the hard fund (metal, wood, ceramics, glass, etc.) of the $2^{\text {nd }}$ order of the Department of Siberia and the Far East. She has been supervising storage of 11.5 thousand items and 15 thousand objects. Since 2013 she has held the position of a leading researcher.

T.Yu. Sem is the author of more than 170 scientific works, including 3 individual monographs, several collective monographs, as well as scientific-methodical and scientific-practical publications, including 17 foreign articles and catalogues.

The main topics of T.Yu. Sem's research interests include theory and methodology of ethnography studies of the peoples of Siberia, problems of ethnoarcheology, ethnogenesis and culture genesis, mythology, shamanism, worldview, folklore and rituals of the Tungus and Manchu peoples of Siberia and the Far East, peoples of adjacent territories (including the Ainu and Nivkh peoples), as well as problems of art, religious beliefs, burial and memorial rites and related beliefs, the semantics of ritual objects. Besides, T.Yu. Sem participated actively in Russian and regional scientific and practical conferences (REM, MAE, Institute of Peoples of the North RSPU, SaintPetersburg, Moscow, Yakutia), as well as foreign conferences and seminars on the spiritual culture of the Tungus-Manchu peoples and peoples of the Far East (Poland, USA, Estonia, Spain). 
T.Yu. Sem took an active part in 10 ethnographic expeditions to study the peoples of Siberia and the Far East (the Evenkis in Olenyok and Kharyalakh rural localities in the Olenyok District of the Yakut ASSR in 1988-1990; the Evens in the Kolyma District of the Yakut ASSR in 1982; the Oroks and the Upper Negidals in 1986; the Nanais in Sikachi-Alyan, Sheremetyevo, Kharyalakh rural localities on the Ussuri River in 1970, in Naykhin in 1981, in Bolon, in Upper Nergen, in Upper Ekon in 1972; the Udege people in the Bikin River basin in 1975 and the Khor River basin in 1981); the Kirghiz people and the Dungans in Central Asia, when she was fourth year student in 1979. As a result of her trips, she collected about 500 ethnographic items belonging to the peoples of Siberia and the Far East for REM.

T.Yu. Sem made a great contribution to the educational and methodological work of the Russian Ethnographic Museum, for more than 10 years she has been in charge of guided tours of the museum's expositions (highlight tours and exhibitions featuring different regions, excursions with religious focus). She has been a visiting lecturer and founded a project to create an exposition in the regional museum of Olenyok, Republic of Sakha (Yakutia) (1988-1990); together with V.V. Gorbacheva she developed the design of a historical and ethnographic museum in Lensk (Yakutia) (2001). Also, T.Yu. Sem developed a guidelines for lecturing in REM on Evenki culture.

Apart from that, T.Yu. Sem played a major part in creating exhibitions in the museum. The researcher is the co-author of the concept of several exhibitions, including those of the culture and art of the peoples of Siberia, the Yakuts, the Ainu people, and shamanism, followed by publications in Russian and foreign journals (Netherlands, USA, Germany, Italy, Spain, Japan). T.Yu. Sem participated in the reconstruction of the exposition "Peoples of Siberia" (the Evenks section). She is the initiator, the author of the ideas and themes of new museum projects on the shamanism of the Siberian peoples (co-authored with K.Yu. Solov'eva and V.V. Gorbacheva) and on Buddhism of the Siberian peoples (coauthored with M.V. Fedorova and S.V. Romanova).

For 20 years from 1989 to 2009 T.Yu. Sem worked at the Department of Culture of the Peoples of the Far North, then she was a senior lecturer at the Department of Ethnoculturology in the Institute of the Peoples of the North of the Russian State Pedagogical University named after A.I. Herzen, in 2007 she got a position of an associate professor. T.Yu. Sem gave lectures on mythology, traditional beliefs and folk knowledge of the Peoples of the Far North, ethnology and ethnography of different groups concerning life world, history and ethnography of the Peoples of the Far North, 
ethnographic museology, as well as on traditional culture of the Peoples of the Far North and their folklore.

T.Yu. Sem received a number of official awards: letters of acknowledgement from the Ministry of Culture to thank her for decades-long conscientious work in the Russian Ethnographic Museum (2001), a Certificate of Honour from the Institute of the Peoples of the North of the Russian State Pedagogical University named after A.I. Herzen for many years of dutiful work on the organization of training, methodical and research work with students (2004), award for the best edition of 2006 from the Ministry of Culture for the album "On the verge of worlds. Shamanism of the Siberian peoples" (as a co-author, 2006). In 2012, she was awarded the anniversary badge of honour "380 Years of Yakutia with Russia" from the Republic of Sakha (Yakutia) for constant contact with the Yakut creative culture, publications dedicated to the peoples of Yakutia and the preparation of three joint exhibitions together with the United Regional Museum of the Peoples of Yakutia and the Russian Ethnographic Museum. In 2016, T.Yu. Sem was awarded a badge of honour " $100^{\text {th }}$ anniversary of St. Petersburg Datsan" for compiling an album "Buddhist culture of the peoples of Russia" together with the representatives of the Department of Siberia and the Far East of the REM and organising the eponymous exhibition in the REM, and also for the publication of a collaborative album "Buddhism of Russia" in English in Delhi, and for scientific articles on the Buddhist-shamanic syncretism among the Tungus-Manchu peoples of Siberia and the Far East.

To sum up, T.Yu. Sem is a major museum specialist, a recognized expert in ethnography of the Tungus-Manchu peoples and a promising investigator who takes advantage of modern methods of scientific research.

\section{List of T.Yu. Sem's main scientific works}

Sem, T.Yu. (1984). Tipy pogrebenii $\mathrm{i}$ arealy ikh rasprostraneniia u tungusoman'chzhurskikh narodov Priamur'ia i Primor'ia (konets XIX-XX vv.) [Types of burials and areas of their spread among the Tungus-Manchu peoples in the Amur region (Outer Manchuria) and Primorye (Primorsky Krai) $\left(19^{\text {th }}-20^{\text {th }}\right.$ centuries)], In Kul'tura narodov Dal'nego Vostoka: traditsii i sovremennost' [Culture of the peoples of the Far East: traditions and modernity]. Ed. by N.K. Starkova, L.E. Fetisova, S.F. Karabanova, 109119. Vladivostok: Far Eastern Research Centre of the Academy of Sciences of the USSR.

Sem, T.Yu. (1986). Traditsionnyi etnograficheskii kompleks manegrov [Traditional ethnographic complex of the Manjagirs], In Subetnosy v SSSR. Sbornik nauchnykh trudov [Subethnoses in the USSR. Collection of scientific articles]. Ed. by 
A.V. Konovalov, 92-109. Leningrad, Ministry of Culture of the USSR, State Museum of Ethnography of the Peoples of the USSR.

Sem, T.Yu. (1986). Religioznye predstavleniia tunguso-man'chzhurskikh narodov o zhiznennykh silakh cheloveka i ikh vmestilishchakh [Religious ideas of the TungusManchu peoples on the vital forces of man and their carriers], In Fol'klor i etnografiia narodov Severa: mezhvuzovskii sbornik nauchnykh trudov [Folklore and ethnography of the Peoples of the North: Interuniversity collection of scientific articles], 57-78. Leningrad, Herzen SPU.

Sem, T.Yu. (1990). Traditsionnye predstavleniia negidal'tsev o mire i cheloveke [Traditional ideas of the Negidals about the world and man], In Religiovedcheskie issledovaniia $v$ etnograficheskikh muzeiakh: Sbornik nauchnykh trudov [Religious studies in ethnographic museums: Collection of scientific articles], 90-113. State Museum of Ethnography of the Peoples of the USSR.

Sem, T.Yu. (1991). Dinamika etnokul'turnykh protsessov v pogrebal'noi obriadnosti narodov iuga Dal'nego Vostoka SSSR (XVII-XIX vv.) [Dynamics of ethnocultural processes in the burial rites of the southern peoples of the Far East of the USSR (the $17^{\text {th }}-19^{\text {th }}$ centuries)], In Etnokul'turnye protsessy. Traditsii $i$ sovremennost' [Ethnocultural processes. Traditions and modernity], 203-226. Leningrad, State Museum of Ethnography of the Peoples of the USSR.

Sem, T.Yu. (1991). Semantika obrazov pervoistochnika zhizni u tungusoiazychnykh narodov iuga Dal'nego Vostoka kontsa XIX - nachala XX vv. i ikh srednevekovye paralleli [Semantics of images of the origin of life among the Tungus-speaking southern peoples of the Far East in the end of the $19^{\text {th }}$ century - beginning of the $20^{\text {th }}$ century and their medieval analogues], In Rekonstruktsiia drevnikh verovanii: istochniki, metod, tsel' [Reconstruction of ancient beliefs: sources, method, purpose], 179-192. SaintPetersburg, State Museum of the History of Religion.

Sem, T.Yu. (coauthored with K.Iu. Solov'eva) (1992). Vystavka "Na grani mirov: Shamanizm narodov Sibiri v sisteme obriadov" v REM [The exhibition "On the verge of worlds: Shamanism of the Siberian peoples in the ritual system" in the REM], In Materialy Chetvertykh Sibirskikh chtenii, 12-14 okt. 1992, k 90-letiu so dnia rozhdeniia A.A. Popova: tezisy dokladov [Proceedings of the Fourth Siberian Readings, October 12-14, 1992, devoted to the $90^{\text {th }}$ anniversary of A.A. Popov: abstracts of papers], 55-56. St. Petersburg, MAE RAS.

Sem, T.Yu. (1993). Ideia kosmicheskoi sviazi v atributike evenskikh shamanov [The idea of space relation in the attributes of the Even Shamans], In Etnosemiotika 
ritual'nykh predmetov: Sbornik nauchnykh trudov [Ethnosemiology of ritual objects: Collection of scientific articles]. Editor-in-chief A.B. Ostrovskii, 127-140. SaintPetersburg, Russian Ethnographic Museum.

Sem, T.Yu. (1993). Personazhi mifa o pervoi smerti u tungusoiazychnykh narodov Priamur'ia i Primor'ia [The characters of the myth about the first death spread among the Tungus-speaking peoples of the Amur region (Outer Manchuria) and Primorye (Primorsky Krai)], In Traditsionnye verovaniia v sovremennoi kul'ture etnosov [Traditional beliefs in the contemporary culture of ethnoses], 167-184. SaintPetersburg, Publishing House "Evropeiskii Dom".

Sem, T.Yu. (1995). Amurskii kosmogonicheskii mif: model' i variant [Amur cosmogonic myth: model and variants], In Sistemnye issledovaniia vzaimosviazei drevnikh kul'tur Sibiri i Severnoi Ameriki: Dukhovnaia kul'tura [System studies of interrelations between ancient cultures of Siberia and North America: Spiritual culture]. Editor-in-chief E.A. Okladnikova, 3, 111-142. Saint Petersburg, MAE RAS.

Sem, T.Yu. (1996). "Vvedenie v etnologiiu". Programma kursa lektsii ["Introduction to ethnology". Program of the lecture course], In Kul'turologiia. Kompleks uchebnykh programm i metodicheskikh razrabotok dlia studentov FNKS RGPU [Culture studies. A complex of syllabi and methodological guidelines for students of the Russian State Pedagogical University, Faculty of the Peoples of the Far North], 1, 13-25. Saint Petersburg, Herzen SPU.

Sem, T.Yu. (1997). Shamanizm v ritual'noi praktike narodov Sibiri i Dal'nego Vostoka [Shamanism in the ritual practice of the peoples of Siberia and the Far East], In Sistemnye issledovaniia vzaimosviazei drevnikh kul'tur Sibiri i Severnoi Ameriki: Dukhovnaia kul'tura [System studies of interrelations between ancient cultures of Siberia and North America: Spiritual culture]. Editor-in-chief E.A. Okladnikova, 5, 85-122. Saint Petersburg, MAE RAS.

Sem, T.Yu. (1999). “Mifologiia, narodnye verovaniia iznaniia narodov Sibiri”. Programma kursa lektsii ["Mythology, popular beliefs and knowledge of the peoples of Siberia". Program of the lecture course], In Kul'turologiia. Kompleks uchebnykh programm i metodicheskikh razrabotok dlia studentov FNKS RGPU [Culture studies. A complex of syllabi and methodological guidelines for students of the Russian State Pedagogical University, Faculty of the Peoples of the Far North], 2, 39-52. Saint Petersburg, Herzen SPU.

Sem, T.Yu. (2001). B.O. Pilsudskii kak issledovatel' traditsionnogo mirovozzreniia ainov (k problem interpretatsii ritual'nykh palochek inau) [B.O. Pilsudsky as a researcher of the traditional worldview of the Ainu peoples (on the problem of interpretation of 
ritual sticks inau)], In B. Pilsudski and futubatei shimei - an excellent charter in the history of Polish - Japanese relations. (Materials of the III International Conference on B. Pilsudsky and his scientific heritage, 1999, Krakow), 151-155. Poznan.

Sem, T.Yu. (2002). Tungusskaia model' mira: semiotika i istoricheskaia dinamika [The Tungus model of the world: semiotics and historical dynamics], In Etnicheskoe edinstvo i spetsifika kul'tur. Materialy pervykh v SPb etnograficheskikh chtenii [Ethnic unity and specificity of cultures. Materials of the first in St. Petersburg ethnographic readings], 114-118. Saint Petersburg, Russian Ethnographic Museum.

Sem, T.Yu. (2002). Semantika ritual'nykh predmetov v kartine mira ainov po kollektsiiam REM [Semantics of ritual objects in the Ainu worldview as according to REM collections], In Izvestiia Instituta naslediia Bronislava Pilsudskogo [News of the Bronislaw Pilsudski Heritage Institute], 6, 193-214. Yuzhno-Sakhalinsk.

Sem, T.Yu. (2002). Germenvtika sakral'nykh predmetov u narodov Sibiri. Novye podkhody $\mathrm{k}$ muzeinoi atributike. $\mathrm{K}$ postanovke problem [Hermeneutics of sacral objects among the peoples of Siberia. New approaches in museum sets of attributes. On the statement of the problem], In Muzei na rubezhe vekov. Materialy nauchnoprakticheskoi konferentsii, posviashchennoi 110-letiu Iakutskogo gosudarstvennogo muzeia istorii i kul'tury narodov Sever aim. E.M. Iaroslavskogo [Museum at the turn of the century. Materials of the scientific-practical conference dedicated to the $110^{\text {th }}$ anniversary of the Yakut State Museum of the History and Culture of the Peoples of the North named after E.M. Yaroslavsky], November 1, 2001, 86-104. Yakutsk, Publishing House of the Department of Elementary and Secondary Professional Education of Ministry of Education, Republic of Sakha (Yakutia).

Sem, T.Yu. (2003). Modeli mira tungusoiazychnykh narodov Nizhnego Amura i problem mental'nosti (traditsii i ikh sovremennaia interpretatsiia) [World models of the Tungus-speaking peoples of the Lower Amur and the problem of mentality (traditions and their modern interpretation)], In Sibir'. Problemy sibirskoi identichnosti [Siberia. Problems of Siberian identity]. Editor-in-chief A.O. Borponoev, 134-151. Saint Petersburg, Asterion.

Sem, T.Yu. (2003). Modeli mira, panteon dukhov i predkov, kalendarnye obriady, shamanism v obriadakh nanaitsev [World models, pantheon of spirits and ancestors, calendar rites, shamanism in Nanai rites], In Istoriia i kul'tura nanaitsev. Istoriko-etnograficheskie ocherki [History and culture of the Nanais. Historical and ethnographic essays]. Editor-in-chief V.A. Turaev, 162-194. Saint Petersburg, "Nauka" of Far Eastern Research Centre. 
Sem, T.Yu. (2004). Pervye shamanskie predki tungusov v fol'klore i verovaniiakh(K problem genezisa belogo shamanstva) [The first shaman ancestors of the Tungus people in folklore and beliefs (On the problem of the white shamanism genesis)], In Problemy Sibirskoi mental'nosti [Issues of the Siberian mentality]. Ed. by A.O. Boronoev, 200217. Saint Petersburg, Asterion.

Sem, T.Yu. (2004). Tekstil'noe proizvodstvo i khudozhestvennaia obrabotka tkanei [Textile production and elaborate processing of fabrics], In Traditsionnye promysly $i$ remesla narodov Rossii. Uchebnoe posobie dlia studentov vysshikh uchebnykh zavedenii [Traditional crafts and handicrafts of different nations in Russia. Textbook for students of higher educational institutions], 74-148. Saint Petersburg, Publishing House "Drofa".

Sem, T.Yu. (coauthored with L.V. Andreeva) (2004). Odezhda evenov [Clothes of the Evens], In Khudozhestvennaia obrabotka mekha i kozhi u narodnostei Krainego Severo-Vostoka. Eveny [Elaborate processing of fur and skin (leather) among the peoples of the Far North-East], 2, The Evens, 11-39. Magadan.

Sem, T.Yu. (2004). Animizm, Kul't predkov, Magiia, Kul't bliznetsov, Totemizm, Piktogramma, Evenki, Iukagiry [Animism, Cult of ancestors, Magic, Cult of twins, Totemism, Pictogram, the Evenks, the Yukagirs], In Severnaia entsiklopediia [Northern Encyclopedia], 34-35; 467-469; 526-527; 463-464; 467-469; 733-734; 1105-1109; 1140-1144. Moscow.

Sem, T.Yu. (2004). Tekstil'noe proizvodstvo i khudaozhestvennaia obrabotka tkanei [Textile production and elaborate processing of fabrics], In Traditsionnye promysly i remesla narodov Rossii. Uchebnoe posobie dlia uchashchikhsia 9-11 klassov [Traditional crafts and handicrafts of different nations in Russia. Textbook for students of $9^{\text {th }}-11^{\text {th }}$ grades], 60-120. Saint Petersburg, Publishing House "Drofa".

Sem, T.Yu. (2004). Traditsionnye drevnie verovaniia [Traditional ancient beliefs], In Moskva mnogonatsional'naia. Ofitsial'noe izdanie Pravitel'stva Moskvy. Religiia, kn. 2 [Multinational Moscow. Official bulletin of the Moscow Government. Religion, 2], 607-690. Moscow, "Book Union” Foundation.

Sem, T.Yu. (2006). (as a compiler and an author of the introduction, studies, appendix, conclusions, selection of figure). In Shamanizm narodov Sibiri. Etnograficheskie materialy XVIII-XX vv. Khrestomatiia [Shamanism of the Siberian peoples. Ethnographic materials of the $18^{\text {th }}-20^{\text {th }}$ centuries. Chrestomathy]. Saint Petersburg: Philological Faculty of St. Petersburg State University, 628 p.

Sem, T.Yu. (coauthored with K.Iu. Solov'eva and V.V. Gorbacheva) (2006). Shamanizm narodov Sibiri. Kontseptsiia izdaniia. Annotatsii [Shamanism of the 
Siberian peoples. The concept of the publication. Abstracts], In Na grani mirov. Shamanizm narodov Sibiri. (Iz sobraniia Rossiiskogo etnograficheskogo muzeia: Al'bom) [On the verge of worlds. Shamanism of the Siberian peoples, (From the collection of the Russian Ethnographic Museum: Album)], Ed. by V.M. Grusman. Moscow, Publishing\&Printing Centre "Khudozhnik i kniga", 296 p.

Sem, T.Yu. (2007). Simvolika i semantika obriadovoi odezhdy tungusov (k ikonografii bogov plodorodiia) [Symbolic and semantic system of the ritual clothes of the Tungus people (on the iconography of the gods of fertility)], In Vestnik SanktPeterburgskogo gosudarstvennogo universiteta [Bulletin of the St. Petersburg State University], 4, 245-256.

Sem, T.Yu. (2007). Semiotika ritual'nykh predmetov ainov v kollektsii Rossiiskogo etnograficheskogo muzeia [Semiotics of the Ainu ritual objects in the collection of the Russian Ethnographic Museum], In Rossiiskii etnograficheskii muzei. Katalog ainskikh kollektsii (na russkom i iaponskom iazykakh) [Russian Ethnographic Museum. Catalogue of Ainu collections (in Russian and Japanese)], 135-141. Tokyo, Chiba University.

Sem, T.Yu. (2007). Verkhovnyi panteon tunguso-man'chzhurskikh narodov Sibiri i Dal'nego Vostoka (XIX-XX vv.): tipologiia i semantika obrazov [The supreme pantheon of the Tungus-Manchu peoples in Siberia and the Far East $\left(19^{\text {th }}-20^{\text {th }}\right.$ centuries): typology and semantics of images], In The Thesis for a Degree of Candidate of Historical Sciences. Saint Petersburg, 28 p.

Sem, T.Yu. (2007). Programma "Fol'klorno-etnograficheskaia praktika" [The program "Folklore and Ethnographic Practice"], In Culturologiia. Uchebnometodicheskii kompleks [Culture studies. Textbook and methodological complex], 3, 75-83. Saint Petersburg, Publishing House of Herzen SPU.

Sem, T.Yu. (2009). Filosofiia sviashchennogo kamnia v geo-kul'turnom prostranstve Baikalo-amurskogo regiona (k kontseptsii zhizni prirodno-mirovozzrencheskoi kul'tury tungusov) [Philosophy of a sacred stone in the geo-cultural space of the Baikal-Amur region (on the concept of life in the natural worldview and culture of the Tungus people)], In Noosferizm. Arkticheskii vzgliad na ustoichivoe razvitie Rossii $i$ chelovechestva $v$ XXI veke [Noospherism. Arctic view on the sustainable development of Russia and mankind in the $21^{\text {st }}$ century (editor-in-chief A.I. Subetto)], 2, 2, 80-103. Saint Petersburg, Asterion.

Sem, T.Yu. (2010). Koreiskie teatral'nye marionetki v kontekste Dal'nevostochnykh traditsii [Korean theatre puppets in the context of the Far Eastern traditions], 
In Kiunerovskii sbornik [Kühner's collection]. Editors-in-chief E.V. Ivanova, D.A. Samsonov, 345-355. Saint Petersburg, MAE RAS.

Sem, T.Yu. (coauthored with S.V. Bereznitskii and V.A. Turaev) (2010). Verovaniia i obriady [Beliefs and rites], In Istoriia i kul'tura Dal'nevostochnykh evenkov. Istroikoetnograficheskie ocherki [History and culture of the Far Eastern Evenks. Historical and ethnographic essays], 222-251. Saint Petersburg, "Nauka".

Sem, T.Yu. (2011). Arkhaichnye obrazy Vselennoi v naskal'nykh izobrazheniiakh narodov Sibiri i Dal'nego Vostoka i shamanskie mesta sily [Archaic images of the Universe in rock paintings of the peoples of Siberia and the Far East and shamanic places of power], In Materialy konferentsii s mezhdunarodnym uchastiem 26 oktiabria 2010 g. "Homo-Eurasicus" v sakral'nykh landshaftakh drevnosti [Proceedings of the conference "Homo-Eurasicus" in the sacral landscapes of antiquity with international participation, October 26, 2010]. Editor-in-chief K.M. Oganian, 130-140. SaintPetersburg, Saint-Petersburg State University of Engineering and Economics.

Sem, T.Yu. (2011). Buddiisko-shamanskii simbioz tungusoiazychnykh narodov Vostochnoi Sibiri i Dal'nego Vostoka [Buddhist-shamanic symbiosis of the Tungusspeaking peoples of Eastern Siberia and the Far East], In Pamiat' mira: istorikodokumental'noe nasledie buddizma: Materialy mezhdunarodnoi nauchno-prakticheskoi konferentsii 25-26 noiabria $2010 \mathrm{~g}$. [Memory of the world: historical and documentary heritage of Buddhism: Proceedings of the international scientific and practical conference, November 25-26, 2010], 178-188. Moscow, Publishing Center of RSUH.

Sem, T.Yu. (coauthored with Iu.A. Sem, L.I. Sem) (2011). Materialy po traditsionnoi kul'ture, fol'kloru i iazyku orokov. Dialektologicheskii oroksko-russkii slovar'. Monografiia [Materials on the Oroks' traditional culture, folklore and language. Dialectological Orok-Russian dictionary. Monograph], In Trudy instituta istorii, arkheologii i etnografii narodov Dal'nego Vostoka, T. XIV. Etnograficheskie issledovaniia [Proceedings of the Institute of History, Archaeology and Ethnography of the Peoples of the Far East. Ethnographic research], 14. Vladivostok, "Dal'nauka".

Sem, T.Yu. (as an author and a compiler) (2011). Shamanizm narodov Sibiri: etnograficheskie materialy XVI-XXvv. Khrestomatiia $v$ dvukh tomakh [Shamanism of the peoples of Siberia: ethnographic materials of the $16^{\text {th }}-20^{\text {th }}$ centuries. Chrestomathy in 2 volumes], 1, 2, $2^{\text {nd }}$ edition, corrected and enlarged. Saint Petersburg, Philological Faculty of SPbSU; "Nestor-Istoriia”, vol. 1., 496 p., vol. 2., 482 p.

Sem, T.Yu. (2012). Naskal'nye izobrazheniia sakral'nogo vremeni i ikh istoricheskoe prochtenie $\mathrm{v}$ fol'klore tunguso-man'chzhurov [Rock paintings of sacral time and their 
historical interpretation in the folklore of the Tungus-Manchu peoples], In"HomoEurasicus" $v$ dukhovnykh $i$ sotsial'nykh realiiakh vremeni. Materialy Vserossiiskoi nauchno-prakticheskoi konferentsii 26 oktiabria 2012 g. ["Homo Eurasicus" in the spiritual and social realities of time. Proceedings of the All-Russian scientific and practical conference October 26, 2012]. Editor-in-chief E.A. Okladnikova, 44-64. Saint Petersburg, "Inzhekon”, Saint-Petersburg State University of Engineering and Economics.

Sem, T.Yu. (2013). Verkhovnyi panteon tunguso-man'chzhurskikh narodov Sibiri i Dal'nego Vostoka: XIX-XX vv. Tipologiia i semantika obrazov. Monograph [The supreme pantheon of the Tungus-Manchu peoples of Siberia and the Far East: $19^{\text {th }}$ $20^{\text {th }}$ centuries. Typology and semantics of images. Monograph]. Yuzhno-Sakhalinsk, Sakhalin Regional Museum of Local Lore, 240 p.

Sem, T.Yu. (2015). Kartina mira tungusov: panteon (Semantika obrazov i etnokul'turnye sviazi). Istoriko-etnograficheskie ocherki. Monografiia [The worldview of the Tungus people: pantheon (Semantics of images and ethno-cultural ties). Historical and ethnographic essays. Monograph]. Saint Petersburg, Philological Faculty of SPbSU, 640 p.

Sem, T.Yu. (2015). Shamanizm evenkov (po materialam Rossiiskogo etnograficheskogo muzeia). Monograph [Shamanism of the Evenks (based on the materials of the Russian Ethnographic Museum). Monograph]. Saint Petersburg, Academy of Cultural Studies, $292 \mathrm{p}$.

Sem, T.Yu. (2016). Shamanizmi verovaniia tungusoiazychnykh narodov Priamur'ia i Primor'ia v muzeinykh kollektsiiakh Iu.A. Sem i L.I. Sem [Shamanism and beliefs of the Tungus-speaking peoples of the Amur region (Outer Manchuria) and Primorye (Primorsky Krai) in museum collections by Iu.A. Sem and L.I. Sem], In Problemy izucheniia traditsionnykh soobshchestv Tikhookeanskoi Rossii. K 90-letiiu so dnia rozhdeniia Iu.A. Sema i L.I. Sem [Problems of studying traditional communities of the Pacific Russia. On the occasion of the $90^{\text {th }}$ anniversary of Iu.A. Sem and L.I. Sem], 72-84. Vladivostok, "Dal'nauka".

Sem, T.Yu. (co-authored with V.N. Davydov, V.V. Simonova, D. Brandishauskas). (2016). Ogon', voda, veter $i$ kamen' v evenkiiskikh landshaftakkh. Otnosheniia cheloveka i prirody v Baikal'skoi Sibiri. Kollektivnaia monografiia [Fire, water, wind and stone in the Evenk landscapes. Relations between man and nature in the Baikal Siberia. Collective monograph]. Saint Petersburg, MAE RAS, 196 p.

Sem, T.Yu. (2017). Obraz bozhestva plodorodiia - shamanskogo dukha-posrednika tunguso-man'chzhurskoi mifologii $\mathrm{v}$ aspekte etnokul'turnykh sviazei [The image of 
the fertility deity, a shamanistic spirit and a mediator in the Tungus-Manchu mythology as regards ethno-cultural ties], In "Homo-Eurasicus" v sistemakh etnokul'turnykh sviazei. Kollektivnaia monografiia po materialam VII mezhdunarodnoi konferentsii 25 oktiabria 2016 g. ["Homo-Eurasicus" in the systems of ethno-cultural ties. Collective monograph based on the materials of the $7^{\text {th }}$ International conference, October 25, 2016]. Editors-in-chief E.A. Okladnikova, V.A. Popov. Moscow, Berlin, Direct Media, $359 \mathrm{p}$.

\section{In foreign languages}

Sem, T. (1997). Het wereldbeeld van de sjamaan, In Wat bezielt de sjamaan? genezing. extase. kunst, 33-57. Amsterdam. (in Dutch).

Sem, T. (1999). Schamanische symbole und rituale in Sibirien und dem Fernen Osten, In Schamanen zuischen mythos und modern, 11-40. Leipzig. (in German).

Sem, T. (2003). Semiotica dei rituali degli sciamani della Siberia e dell'Estremo Oriente, In Il volo dello sciamano. Simboli ed arte delle culture Siberiane, 95-105. Roma, Museo Nazionale delle Arti e Tradizioni Popolari. (in Italian).

Sem, T. (coauthored with K. Solov'eva, V. Gorbacheva) (2006). Shamanism of the Peoples of Siberia Between worlds, In Shamanism of the Peoples of Siberia. From collection of the Russian Museum of Ethnography, 33-280. St. Petersburg, Moscow. (in English).

Sem, T. (2008-2009). Kosmologische Vorstellungen sibirischer, In Schamanen sibiriens. Magier. Mittler. Heiler (Erich Kasten (Hgr). Reimer Linden Museum, Stuttgart. Staatliches Museum fur Volkerkunde und Dietrich reamer Verlag Gmbh., 50-57. Berlin. (in German).

Sem, T. (2008-2009). Schamanen der Evenken, In Schamanen sibiriens. Magier. Mittler. Heiler (Erich Kasten (Hgr). Reimer Linden Museum, Stuttgart. Staatliches Museum fur Volkerkunde und Dietrich reamer Verlag Gmbh., 152-155. Berlin. (in German).

Sem, T., Fedorova, M.V. (2008-2009). Schamanismus und Buddhismusbei Volkern Sibiriens, In Schamanen sibiriens. Magier. Mittler. Heiler (Erich Kasten (Hgr). Reimer Linden Museum, Stuttgart. Staatliches Museum fur Volkerkunde und Dietrich reamer Verlag Gmbh., 164-167. Berlin. (in German).

Sem, T. (2010). Le spedizioni etnografiche russe e lo sciamanesimo siberianj trala fine del XIX 1 inizio del XX secolo, In La Venere e lo sciamano. L influsso dello sciamanesimo siberiano sulle arti e la cultura russa del Novecento a cura di V. Parisi, 63-87. Universita degli studi Napoli "L'orientale". (in Italian). 
Sem, T. (coauthored with N. Zhukovskaia, M. Fedorova, S. Romanova and O. Khizhniak). (2011). Buddhism in Russia. Catalogue, In Cosmolody and Panteon. Monastery Buddhism. Folk Buddhism (published on the occasion of Buddhism in Russia exhibition), 3-179. Delhi. (in English).

Sem, T. (2012). The collections of Bear-Festival in the Russian Museum of Ethnography. The Peoples of Amur-Sakhalin Region (the Nivkh and Orok peoples), In Bulletin of the Hokkaido Museum of Northern Peoples (translated to Japanese by Sh. Ogihara), 21, 95-108. (in English).

Sem, T. (2012). Veneraa Rahvaste samanismist, In Go Reisiajakiri, 3, 25-27. (in Estonian).

Sem, T. (coauthored with V.V. Gorbacheva, I.A. Karapetova, S.V. Romanova, K.Yu. Solov'eva, M.V. Fedorova). (2013). Autores de las fichas catalogra ficas, In Entre los mundos el chamanismo en los pueblos de Siberia. Spain, 247 p. (in Spanish).

Sem, T. (2013). The Smaller shamanic idols of the Peoples of Siberia, In The Russian Avant-garde Siberia and the East. Edited by John E. Bowlt, N. Misler, E. Petrova, 8793. Skipa. Florence: Palazzo Strozzi. (in English).

Sem, T.Yu. (2013). Piccoli idoli sciamanici dei popoli della Siberia, In Fuocoeghiaccia L’Avanguardia russa, la Siberia. (in Italian).

\title{
К 60-летию известного этнографа-тунгусоведа Татьяны Юрьевны Сем
}

\author{
В.Н. Давыдов \\ Музей антропологии и этнографии \\ им. Петра Великого РАН (Кунсткамера) \\ Россия, 199034, Санкт-Петербург, \\ Университетская наб., 3
}

\begin{abstract}
Данная публикация посвящена 60-летию известного ученого-тунгусоведа Т.Ю. Сем. В статье описывается вклад Т.Ю. Сем в этнографическую науку, приводится список основных трудов ученого.

Ключевые слова: тунгусоведение, Российский этнографический музей, этнография народов Сибири.
\end{abstract}

Научная специальность: 24.00.00 - культурология. 